\title{
Democratic Punishment and the Archive of Violence: Publicity, Prisons and Corporal Excess in Antebellum New York
}

\begin{abstract}
:
Nineteenth century American prisons were paradoxical institutions. Porous and impermeable, transparent and opaque, open to public view and occluded from sight; prisons clearly functioned as containers for raw coercion even as they were paraded as paragons of democratic transparency. How did the New York state navigate between these two countervailing positions and how did it explicate the difference between them? This essay explores the problem of penal violence and the state's varied strategies for mitigating its impact. I discuss the varied modes of representing the prison in print, in institutional tours and in official reports and investigations in the antebellum period. The tidy reconstructions of institutional life contained in official reports formed a compelling portrait of an ordered, transparent and disciplined institution. I argue that this representation of prison life was sustained through a tenuous policy of epistemic violence; it relied on the systematic elision and banishment of convict self-narratives, their incapacity in law and in practice to articulate the ontology of suffering in the state's incarceration facilities, as well as a tightly regulated monopoly over the collection and presentation of prison facts.
\end{abstract}

Luca Follis

Lancaster University Law School

Bowland North

Lancaster University

1.follis@lancaster.ac.uk

Biographical Note:

Luca Follis is a Lecturer in Criminology at Lancaster University. His work focuses on the relationship between democracy, citizenship and legal exclusion. 
On January 12, 1826 Rachel Welch, a female convict of Auburn prison, died from complications related to a severe whipping she had received at the hands of Assistant Keeper Ebenezer Cobb. Welch had been a prisoner at Auburn for little over a year and spent her first three months in solitary confinement. During that time, she became pregnant at the hands of a guard, or an inmate that brought her meals, and gave birth to a child in December shortly before she died. In the wake of her death, controversy and scandal engulfed the new prison: both the New York State Senate and the Attorney General initiated investigations and Cobb was tried for assault. ${ }^{1}$

Welch's death represents a watershed in the politics and practice of punishment in New York State affording a unique perspective on the problem of violence in $19^{\text {th }}$ century prisons. Her flogging violated the law of 1819 (which prohibited the whipping of female prisoners) and provides a striking barometer of the incapacity of law and sensibility to restrain the sheer violence that suffused penal space. Although Cobb was convicted of assault and the grand jury uncovered systemic violations of the law, he was fined $\$ 25$ and allowed to

\footnotetext{
${ }^{1}$ See for example: "State Prison," Auburn Free Press, March 22, 1826; "State Prison Commissioner's Report," Auburn Free Press, January 31, 1827; "State Prison," Auburn Free Press, February 28, 1827. The Welch scandal is also summarized in W. David Lewis, From Newgate to Dannemora (1965) pp.94-95 and Ralph S. Herre, "The History of Auburn Prison From the Beginning to About 1867" [PhD dissertation] (1950), p.93.
} 
retain his post; neither the warden nor any other figure of authority at the prison was prosecuted. Indeed, the verdict emboldened penal authorities, led to a dramatic escalation of corporal punishment and helped reshape the state's discourse on violence and its centrality to prison discipline.

At the same time, the controversy and negative publicity that surrounded the incident starkly illustrates the enigma that violence posed for the state. The legitimacy of prisons relied on complex and contradictory rationales framed against the undiscriminating violence and cruelty of colonial punishments, the modern and civilized institutions of democratic order that supposedly replaced them, and the state's evolving projection of public authority. In this sense, the prison was intimately tied to the state project: it fed its narrative of development and order and, next to the Eerie Canal, stood out as the premier public institution of the antebellum period. ${ }^{2}$ Throughout the $19^{\text {th }}$ century, the prison played an integral part in the ideological elaboration of New York State; it represented a site through which the state could frame itself as a coherent unitary authority that embodied democratic tropes of transparency and accountability. Sustaining this image of the prison was complicated and politically unstable: it required bridging the prison's place at the vanguard of the new democratic institutions with the abject violence and dehumanization necessary to maintain a veneer of order and discipline. Rationalizing the portrayal of violence and ensuring that its discursive construction remained consonant with the state's ideological premises necessitated extensive normative articulation.

The critical historiography of $19^{\text {th }}$ century prisons has failed to capture this ambiguity in penal violence, its impact on the wider project of state development, and the active role of the state in navigating the myriad of crises and scandals it engendered. In many accounts,

\footnotetext{
${ }^{2}$ On the prominence of the prison in Antebellum America and its relationship to democracy see: Thomas Dumm, Democracy and Punishment: Disciplinary Origins of the United States (1987), especially ch. 5.
} 
violence is treated as a matter of fact, as a predictable outgrowth of reformist "convenience," as a Northern counterpart to Southern slavery driven by economic profit or, even, as a structural precondition of the $19^{\text {th }}$ century culture. ${ }^{3}$ Even Michel Foucault who set his discussion of discipline against the backdrop of sovereign violence and who sought to emphasize the eclipse of the body as the object of punishment, treats penal violence as a sort of vestige, describing it as "useless" and as a sign of new power relations (penal sovereignty and autonomy) rather than as a fundamental problematic of governance. ${ }^{4}$

Others inspired by the sociology of Norbert Elias have stressed the affinity between the origins of the prison and state formation, emphasizing the state's monopolization of violence and institutional development. According to Spierenburg the severe repressive practices of America's early prisons mirrored the relatively recent pacification of the populace and the rough character of popular sentiments. Pratt's account focuses on the UK and argues that the central motive force in managing penal violence involved the bureaucratization of the prison service in the late $19^{\text {th }}$ century. Bureaucratization, along with a reorientation of elite sensibilities, sanitized penal language and silenced alternative portrayals of what transpired behind prison walls. ${ }^{5}$ Despite focusing on violence as a problematic of governance, the above perspectives fail to account for the very public nature of penal institutions and their existence as "sites of civic activity, public participation, and

\footnotetext{
${ }^{3}$ David Rothman The Discovery of the Asylum: Social Order and Disorder in the New Republic (1971); Adam Hirsch, The Rise of the Penitentiary Prisons and Punishment in Early America (1992) and Rebecca McLennan, The Crisis of Imprisonment Protest, Politics and the Making of the American Penal State (2008); Caleb Smith, The Prison and the American Imagination (2009) and Philip Smith, Punishment and Culture (2008).

${ }^{4}$ Michel Foucault, Discipline and Punish: The Birth of the Prison (1977), pp. 248-249.

${ }^{5}$ Pieter Spierenburg, The Spectacle of Suffering (1984) and " From Amsterdam to Auburn: An Explanation for the Rise of the Prison in Seventeenth Century Holland and Nineteenth Century America," Journal of Social History (1987), pp. 454-455. John Pratt, Punishment and Civilization: Penal Tolerance and Intolerance in Modern Society (2002), p.138.
} 
enlightenment". ${ }^{6}$ American prisons were porous and impermeable, transparent and opaque, open to public view and occluded from sight; they clearly functioned as containers for raw coercion even as they were paraded as paragons of democratic transparency. How did the state navigate between these two countervailing positions and how did it explicate the difference between them?

This essay explores the problem of penal violence and the state's varied strategies for mitigating its impact. I contend that the premier mode of managing violence was to rhetorically and symbolically frame it as both an indispensable facet of the prison's disciplinary structure as well as a moral and democratic tool for reclaiming penal subjects. To this end, in the discussion that follows, I discuss the varied modes of representing the prison in print, in institutional tours and in official reports and investigations in the antebellum period. The tidy reconstructions of institutional life, the neat itemized accounting of food provisions and building supplies, as well as the lengthy descriptive tables filled with the demographic, educational and criminal characteristics of convicts contained in official reports formed a compelling portrait of an ordered, transparent and disciplined institution. Yet this representation of prison life was sustained through a tenuous policy of epistemic violence; it relied on the systematic elision and banishment of convict self-narratives, their incapacity in law and in practice to articulate the ontology of suffering in the state's incarceration facilities, as well as a tightly regulated monopoly over the collection and presentation of prison facts.

\section{Monopolies of Violence and of Facts}

For much of the $19^{\text {th }}$ century, New York State's structural decentralization and high turnovers among legislators represented considerable barriers to formulating general policy or

\footnotetext{
${ }^{6}$ Janet Miron, Prisons, Asylums and the Public: Institutional Visiting in the $19^{\text {th }}$ Century (2011), p.15.
} 
even ensuring continuity in committee planning from session to session; most of the legislation developed by New York in the four decades before the war, for example, was initiated through direct petitions from non-members. ${ }^{7}$ New York's population was extremely hostile to direct taxation (e.g., between 1799 and 1826 property taxes were collected irregularly and between 1826 and 1842 they were not collected at all) and state revenues were primarily derived from an assortment of public land sales, indirect taxes (e.g., lotteries and auction duties) and investments. In particularly difficult times the legislature relied on bank loans to meet its budgetary shortfalls. ${ }^{8}$

The state's solvency problems did not stop it from building the Eerie Canal System in the first decades of the 19th century (amassing a fiscal deficit of \$25 million in the process) or one of the largest custodial systems in the country, but they did generate significant pressure to garner and maintain public support for these endeavors. ${ }^{9}$ In other words, the state's visibility and penetration, in terms of its capacity to organize social relations through institutions (what Michael Mann has called infrastructural power), was highly uneven. ${ }^{10}$ At the same time, the state consistently sought to depict itself as a coherent and progressive public authority whose reach and scope went well beyond its institutional limits. It is because of this gap between the state's actual infrastructural articulation on the one hand and its normative self-projection as a sovereign public authority on the other, that the representation and portrayal of state institutions became so important. The legislature and its officials were eager to have the public acquainted with the inner workings of their penal institutions,

\footnotetext{
${ }^{7}$ Ray L. Gunn, "The Crisis of Authority in the Antebellum States: New York, 1820-1860." The Review of Politics (1979), pp. 283-284

${ }^{8}$ Ibid, p. 287.

${ }^{9}$ William Staples, Castles of our Conscience: Social Control and the American State (1991), p.41.

${ }^{10}$ Michael Mann, "The Autonomous Power of the State: Its Origins, Mechanisms and Results," Archives Européennes de Sociologie (1984), p.189.
} 
whether through news accounts, tourism or annual reports, because transparency and publicity played an important role in the broader process of institutional legitimation.

Print and publication had played similar roles in American state building during the Revolutionary and Republican periods. In that context, reading and writing were reimagined as paradigmatically civic and democratic actions thereby facilitating the fusion of republican ideology with print culture. Republican publication practices and discursive styles promoted a mode of representing government which stressed transparency, virtue and accountability while imagining public readership as abstract, impersonal and capable of evaluating the validity of political claims. ${ }^{11}$ Although the rigid conflation of literary products with political and civil praxis had largely disappeared by the end of the $18^{\text {th }}$ century, the demand for transparency and accountability in government continued to determine the way the $19^{\text {th }}$ century state represented itself.

Throughout this period, Congress and state legislatures became increasingly active in the spheres of knowledge production and print. "Print Statism" promoted a distinctive public sphere infused with strong notes of didacticism and pedagogy that sought, among other things, to tutor its subjects on the complexity of issues faced by modern government. The state assumed a central role within this context, as producer and publisher of "mass, uniform, transparent and authorless facts". ${ }^{12}$ Vast print archives documenting the minutia of public administration as well as the social investigations and inquiries designed to "know" populations and make them "legible" were generated, anticipating modern strategies of information collection.

Managing public impressions and mitigating popular suspicion were central justifications for gathering prison facts and for opening prison doors to the public. Public

\footnotetext{
${ }^{11}$ Michael Warner, The Letters of the Republic: Publication and the Public Sphere in $18^{\text {th }}$ Century America (1990).

${ }^{12} \mathrm{Oz}$ Frankel, States of Inquiry: Social Investigations and Print Culture in $19^{\text {th }}$ Century Britain and America (2006), pp. 9-10; 32-33.
} 
access to state prisons might elicit feelings of revulsion and blood-lust, but the practice of transparency itself would convince "suspicious citizens that the penitentiary had nothing to hide". ${ }^{13}$ Or, as an Assembly member noted in 1823:

"...[I]t may be asked 'why admit visitors at all?' The answer is, that the public would regard the prison as a sort of bastille or inquisition. It would be revolting to the feelings of community, contrary to the spirit of our institutions, and the sentiments of the people; which equally forbid secresy [sic] in the making or the administration of the laws. It might occasion such a prejudice against the system, as to endanger its stability." ${ }^{14}$

The legislature's endorsement of prison tours and its wide dissemination of prison reports formed part of a set of practices designed to make the prison, and by extension the state, available for public consumption. The two formed part of a representational set or loop: visits and tours augmented and gave physical presence to the prison's portrayal in print. Print (in the form of official reports and sketches of institutional life) provided a convenient medium for rendering visible those facts of prisons that could not be readily inspected by the public. The simple, open and accessible language that characterized the prison system's annual reports offered an unproblematic portrait of institutional life - a sanitized representation of prisons within which order, regularity and professionalism reigned unchallenged. So evocative was this portrayal that reformers like Louis Dwight advocated the adoption of some of Auburn prison's principles within families, schools, colleges and factories. ${ }^{15}$

The representations contained in these reports also formed the central resource for prison facts and information regarding penal developments. Their content saturated the public

\footnotetext{
${ }^{13}$ Gershom Powers, quoted in: W. David Lewis, From Newgate to Dannemora (1965), p.118. ${ }^{14}$ New York State Assembly (NYSA), Journal of the Assembly of New York (1823), p.29.

${ }^{15}$ Boston Prison Discipline Society (BPDS), Fourth Report of the Board of Managers of the Prison Discipline Society (1829), pp. 61-63.
} 
sphere through the reports of prison discipline societies, reformer pamphlets and tracts, as well as newspaper and magazine accounts conflating the discussion of penal matters with the perspective of authority. Thus, the production of prison facts was a deeply political project orchestrated to further the state's hegemony over penal ideas and silence alternative characterizations; it was pivotal in reconciling the image of the prison system and penitentiary consumed domestically and abroad with the deeply dysfunctional reality of its everyday administration.

Maintaining the pubic façade of the prison was no small matter. For example, in 1820, just 23-odd years after New York had embarked on its first penitentiary project, there was open discussion in the State Assembly of abandoning the endeavor and returning to corporal punishment. ${ }^{16}$ Such proposals, much like calls for the creation of penal colonies or for the establishment of new banishment laws, gained traction because the legislature had difficulty imposing a clear normative break between the prison and its previous system of public punishments. Newgate penitentiary, New York's first penal experiment, had been animated by Republican ideas of penitence and reformation; it sought to manage criminality without corporal punishment and through labor. Yet the institution was overcrowded nearly from its inception, its prisoners frequently rioted or escaped and it was chronically in debt. At the same time, although public executions were prohibited in 1835 , thereafter they were removed to the prison yard where they remained "semi-public" spectacles that drew enormous crowds well into the 1880 s.

The sustained co-existence of public executions with imprisonment potentially blurred the boundaries between the violence of the spectacle and that of the prison. While the former was represented as a remnant of barbarity unfit for civil society, the latter was paraded as a paragon of democratic practice. Accounting for penal violence and neutralizing its

\footnotetext{
${ }^{16}$ Lewis, From Newgate to Dannemora, pp. 61-63; Roger Panetta, "Up the River a History of Sing Sing Prison in the $19^{\text {th }}$ Century" [PhD Dissertation] (1999), p.90.
} 
capacity to disrupt official representations of prison order was a persistent problem for the state. Who should wield the instruments of violence and under what conditions could corporal punishment be administered? How many blows or lashes would be permitted? What forms of punishment and duress were crucial elements of the disciplinary system? Was prison discipline possible without violence?

These crucial questions informed the debates between social reformers and penal administrators, as well as providing steady fodder for local press coverage and debate in the public sphere. As will be illustrated in the following section, the problem of penal violence sat at the core of a discursive and definitional struggle concerned with not the place of violence in a democratic order but rather the shape and contours of democratic violence. Under what conditions might penal violence appear civilized and modern? How might one distinguish between despotic and democratic violence? And how might the latter be made sufficiently palpable to a suspicious, wary and increasingly sensitized public?

\section{Democratic Violence and the Law of Necessity}

The collection, presentation and dissemination of prison data were central components of the legislature's narrative of progressive and democratic statehood. The great instability within this representation of penal space concerned how the legislature dealt with the ubiquitous violence that formed the core of the prison's disciplinary framework. It was not violence per se that was unstable. Corporal punishment was institutionalized in many spheres of $19^{\text {th }}$ century life like schools, workshops or the navy. Urban violence, in the form of riots and popular unrest, was also quite common in cities like New York. ${ }^{17}$ Public

\footnotetext{
${ }^{17}$ See for example: Michael Gordon, The Orange Riots: Irish Political Violence in New York City (1993); Michael Pamplona, Riots, Republicanism, and Citizenship (1996); Paul
} 
executions though rare were well attended and popular with both street vendors and the general public until the mid 1830's and even when they were moved to the prison yard, they drew an ample audience. A double execution in the yard of New York's Tombs prison in 1853, for example, involved upwards of 5,000 people assembled outside the prison yard, as well as on the rooftops and from the windows of neighboring buildings. ${ }^{18}$ Likewise it was openly acknowledged that some degree of corporal punishment was a necessary component of penal discipline by even its staunchest opponents. ${ }^{19}$

What made penal violence contentious, suspicious even, was that it was administered behind closed doors. It was a common worry that, much like in the case of private executions, the public might not be able to confirm that “...the requirements of the law, and no more, had been fulfilled"; outside of pubic view it could be difficult to distinguish between necessary (democratic) violence and abject cruelty. ${ }^{20}$ It is clear that the legislature appreciated this distinction early on and sought to minimize the role violence would play in its first penal institution. Newgate penitentiary (ca. 1796-1828) bound its institutional punishments within a tight framework of supervision and oversight. When a convict violated the rules, the assistant keeper was to make note of it and report him to the warden. The warden would hear offenses, allow parties to make their case and choose between the ball and chain, solitary confinement or a restricted diet. It took more than twenty years into the state's prison experience - despite overcrowding, escapes, riots and chronic institutional deficits- to introduce corporal punishment into its prison system. And even when in 1819 the legislature

Weinbaum, Mobs and Demagogues: The New York Response to Collective Violence in the Early $19^{\text {th }}$ Century (1979).

${ }^{18}$ On corporal violence see: Myra Glenn (1984), Campaigns Against Corporal Punishment: Prisoners, Sailors, Children and Women in Antebellum America. On semi-public executions: Michael Madow, "Forbidden Spectacle: Executions, the Public and the Press in $19^{\text {th }}$ Century New York," Buffalo Law Review (1995), p. 513.

${ }^{19}$ Jennifer Grabner, The Furnace of Affliction: Prisons and Religion in Antebellum America (2011), pp.108-111.

${ }^{20}$ New York State Senate (NYSS), Documents of the Senate of the State of New York (1835), Document No. 79, p.4. 
authorized the use of stocks, irons and flogging (up to 39 lashes per incident), corporal punishment could only be administered after a hearing before the board of inspectors and two of them would have to be present when the punishment was meted out. ${ }^{21}$

The legislature clearly recognized the volatility of linking violence to the enforcement of discipline. Corporal punishment openly clashed with the republican discourse that gave the early penitentiaries their legitimacy. Newgate had been informed by the notion that formal consistency and rationalization had not been the sole aims of criminal law reform at the end of the $18^{\text {th }}$ century. Those reforms also represented a more enlightened and civilized manner of punishment, one that befit a new Republic that strived for moral virtue from all its citizens. $^{22}$ For Newgate's inspectors, who envisioned penal administrators as "schoolmasters" and convicts as "pupils," the purpose of punishment was to convince criminals that "vice and suffering", and "virtue and happiness are inseparably connected as cause and consequence". They likened the criminal to an "ignorant, deluded and suffering child of the state" who through "a mild and parental discipline, combining chastisement with instruction" would be lead back to path of "innocence and duty". ${ }^{23}$

Yet if Newgate's legitimacy drew substance from the distinction between the destructive violence of the scaffold and the reformative capacity of penitence, isolation and religious instruction-Auburn and Sing Sing would draw their legitimation from a systematic and highly public critique of the penitentiary ideal. For more than twenty years New York and Pennsylvania would be locked in a bitter and remarkably intense debate over the supremacy of their respective models of prison discipline. It is in the context of these debates

\footnotetext{
${ }^{21}$ NYSA, Journal of the Assembly of the State of New York (1823), pp. 166-167.

${ }^{22}$ For a good statement of this ideal, along with glowing references to Beccaria and other 18th century criminal law reformers: Thomas Eddy, An Account of the State Prison or Penitentiary House, in the City of New York (1801).

${ }^{23}$ NYSA, Journal of the Assembly of the State of New York (1823), pp. 166-167.
} 
and the ensuing success and popularity of the Auburn system that problem of corporal violence became more explicit and prominent.

By the beginning of 1822 the ensemble of silence, lockstep, flogging and congregate labor that formed the core of the Auburn model of discipline were firmly in place. Under the direction of Elam Lynds, the prison quickly became known for its fiscal self-sufficiency, its orderly regimentation of institutional life and its unwavering commitment to flogging. It also became an important tourist destination, attracting visits from citizens, foreign dignitaries, celebrities and state officials. The price of admission was 25 cents for adults and half-price for children. The turnout was impressive, almost tripling the traffic at similar institutions: the state prison in Columbus admitted ca. 4150 persons in 1844 and Charlestown's prison admitted ca. 5951 persons in the years 1842-1844. Auburn in contrast admitted some 14,542 visitors over the course of two years. ${ }^{24}$

In addition to their admission tickets, Auburn's visitors could purchase a densely packed 80-page guidebook for 25 cents. A Brief Account of the Construction, Management and Discipline of the New York State Prison at Auburn by Gershom Powers was published in 1826. The guidebook covers significant ground. It describes in detail the layout, history and rules that govern the institution; it presents the admission procedures, diet and work assignments of prisoners; it extracts prison inspector reports and state commission findings, as well as providing a compendium of criminal law and a lengthy summary of the grand jury trial of a prison officer. It is an exhaustive exposition of the ideological premises of the Auburn system and a thorough depiction of its actual functioning.

At the same time, the guidebook is also a particularly impressive example of state propaganda. The legitimate use of violence is the centerpiece of the document and its justification is presented eloquently in the trial summary of an Auburn assistant keeper

\footnotetext{
${ }^{24}$ Dorothea Dix, Remarks on Prison Discipline in the United States (1845), p.43.
} 
charged for assault and battery of an inmate. This grand jury trial before Judge Walworth took place a few months after the trial of Ebenezer Cobb for the assault and battery of Rachel Welch. Stripped of the controversy surrounding Cobb's trial (i.e., the whipping of a female prisoner in the late stages of pregnancy) it provided an opportunity to rewrite the narrative of corporal violence and its centrality to penal discipline. Walworth's instructions to the jury situate the trial within the larger history of incarceration in New York State. He describes the public's aversion to the English bloody code and the unwillingness of New York juries to convict under it because of its severe and seemingly arbitrary character. In contrast, the penitentiary is depicted as a tremendous advance in cultural humanism. Yet he exhorts the jury to consider the colossal impact of a guilty verdict:

“... [I]f the principles contended for on the part of the prosecution, were adopted to their fullest extent, there would be an end to Prison discipline; and the Penitentiary system in this country would become worse than useless; - the hopes and expectations of philanthropy must wholly fail; and we should be compelled again to resort those sanguinary modes of punishment at which humanity shuddered, or suffer felon to go unpunished, and unrestrainedly to trample upon the rights of his fellow men, to the utter destruction of all social order" (Powers 1826: 64). ${ }^{25}$

In Walworth's reconstruction the penitentiary, only a few decades old, was deep in the grip of a second existential crisis:"[t]his new mode of punishment had lost all its terrors...it neither restrained the cammission [sic] of crimes, or afforded any adequate punishment for the guilty." It was this crisis that had prompted the legislature to reinstitute the use of corporal punishment in 1819. The law sought to ensure that the difference between

${ }^{25}$ Gershom Powers, A Brief Account of the Construction, Management and Discipline of the New York State Prison at Auburn (1826), p.64. 
"the situation of the upright and honest freeman" and that of "vile and degraded convict" could be made manifest: “...the welfare of society, as well as the reformation of the convicts, required that they should feel that they were in reality, the slaves of the state."26 Valorizing this difference and making it symbolically and legally explicit was central to achieving the aims of penal reformers.

In a passage reminiscent of Bentham's utilitarianism, Walworth describes how the "comparatively little bodily suffering" the convict experienced would multiply and be magnified in the "medium of mind". Bodily pain was merely a gateway, an entry point into the suffering of the mind, the true object of the disciplinary system. Further, although the assistant keeper's actions may on their face appear in violation of the law of 1819, in actuality they were founded upon the common law right of keepers to command obedience in the moment and according to the "law of necessity". The distinction between the two, according to Walworth, was that while the law of 1819 regulated the infliction of "salutary punishment" for past offences and was designed to limit the possibility of systemic cruelty on the part of keepers, the "law of necessity" spoke to the practicalities of enforcing authority on the spot. Further, the immediate infliction of corporal punishment to maintain discipline did not preclude the possibility that later, before the committee of inspectors, the prisoner might be sentenced to additional flogging for his violation of prison rules. The law of 1819 restricted the latter exercise of authority not the former.

Walworth's statement illustrates quite well the self-consciousness of state officials in portraying penal violence and rationalizing its use. The subtle and parsing legal rationale displayed by the Judge in his effort to provide corporal violence with a legal and formal imprimatur is astonishing in its circularity. Rather than draw the legal genealogy of the "law of necessity" directly from English common law, which he had earlier disavowed for its

${ }^{26}$ Ibid, p.68. 
barbarity and arbitrariness, he employed a martial analogy. Although the articles of war forbid whipping as punishment for mutiny, if a band of soldiers should refuse a lawful command by their officer, they would be compelled to obey by whipping on the spot. Justice would then require that these soldiers be tried for mutiny later and punished according to the articles of war (which in this case forbid whipping as punishment for treason). ${ }^{27}$ The 1826 legislative committee sent by the Senate to investigate violations of the law of 1819 (spurred by the death of Rachel Welch) echoed Walworth's depiction of the "law of necessity":

"This committee assent to instant punishment when the offense is fresh and flagrant, where it is in the nature of a continuing act, and where the example is of a kind to be infectious or to impair the authority of the officer by delay...We are of opinion instant chastisement should follow. 28

Necessity as violence was structurally bound to disciplinary order, as well as temporally and normatively uncoupled from the kind of cruel and sadistic punishment the law of 1819 was meant to regulate. Yet officials knew that publicly sheer necessity would not be enough to justify the Auburn system's dependence on violence and the predictable scandals that would flow from its excesses. The difference between a just modicum of bodily suffering and cruelty was hardly self-evident and it was more difficult still to maintain the superior humanism of the prison (divested as it was from the legacy of the penitentiary) as compared to public punishments. This point was made all the more imminent given the popularity of

\footnotetext{
${ }^{27}$ Ibid, p.69.

${ }^{28}$ Quoted in: NYSS, "Report of the committee on State prisons, on petitions praying for a law abolishing the use of the whip in our penitentiaries," Documents of the Senate, No. 146 (1846) p.4.
} 
the rival Pennsylvania system, its open disavowal of corporal punishment and claim to be legitimate heir to the republican penitentiary tradition. ${ }^{29}$

Thus part and parcel of legitimating the new state discourse on corporal violence involved silencing alternative characterizations as well as engaging directly the claims of the Pennsylvania system. The views of men like Elam Lynds (builder of Auburn and Sing Sing and three-time warden) or of his protégé Robert Wiltse (warden of Sing Sing throughout the 1830s) were politically dangerous in their enthusiasm for whipping. Lynds in particular, because he was widely credited with formulating the basic tenements of the Auburn system, was frequently quizzed on his views concerning penal discipline. In his view criminals were coarse "cowards" and reform was a naïve illusion. Through the "merciless and just" application of discipline the most one could hope for was to produce a "...silent and insulated human working machine. ${ }^{, 30}$ It is precisely this unsympathetic view of the criminal, and the cries of cruelty and despotism that it engendered in the public sphere, that was potentially destabilizing for the state at a time when the Auburn system was just beginning to enjoy significant fiscal and public success.

A letter written in 1828 by the well-known New York jurist Edward Livingston to the Pennsylvanian reformer Robert Vaux provided the opportunity for the state to distance itself from the sheer enthusiasm for violence displayed by Lynds and to articulate the moral superiority of its system of discipline. Livingston wrote Vaux to caution Pennsylvania against constructing its new prison under the Auburn model. He cited an extensive correspondence with Elam Lynds and noted that despite the imposing "military parade of convicts" about the prison, Auburn would not reform convicts. Quoting Lynds, Livingston emphasized that the warden's chief concern was finding officers that could stifle their

\footnotetext{
${ }^{29}$ Michael Meranze, Laboratories of Virtue: Punishment, Revolution, and Authority in Philadelphia (1996).

${ }^{30}$ Ibid, p.6.
} 
feelings of compassion for prisoners and that would not indulge their charges against the stern requirements of duty. According to Livingston the government of the prison bordered on despotism and the convict's lot was comparable to a slave's:

"[I]t enables the lowest officer of the penitentiary, at his will, to alter the punishment directed by law, to one that the law has discarded as too unequal, and demoralizing, and degrading to be inflicted, and thus to increase the punishment of a slight offence to a degree greater than that designated for one of a deeper dye." ${ }^{31}$

The state's response was swift and eloquent. The following year Powers wrote a letter to the Pennsylvania legislature to defend New York's use of flogging and to distance the official position from that of Lynds. Powers had already given a spirited defense of corporal punishment in his report of 1828 . There he had argued that the sole means of enforcing order in the Pennsylvania system was the "slow torture of starvation". In his graphic rendering the Pennsylvania convict was: “...doomed to pinching hunger, till the skin cleaves to his bones... his limbs paralyzed... and [his] tottering frame indicate a ruined constitution, or some fatal disease that is to terminate his life." He contrasted this potentially interminable anguish with the mild impact of half dozen strokes of the cat at Auburn: without breaking skin or drawing blood the lash could "render [a] wretch into humble submission", 32

Most of the 1829 letter, on the other hand, sought to revise the historical record concerning the origins of the Auburn system. Contrary to what Lynds may have professed, he was not the architect of the disciplinary system but merely an outspoken enforcer of it. He substantiated this claim in the appendix with the sworn affidavits of twenty-nine individuals

\footnotetext{
${ }^{31}$ Edward Livingston, Letter from Edward Livingston to Roberts Vaux, On the Advantages of the Pennsylvania System of Prison Discipline (1828), p.10.

${ }^{32}$ Gershom Powers, Report of Gershom Powers, Agent and Keeper of the State Prison at Auburn (1828), pp. 97-98.
} 
(keepers, officers, inspectors and guards) that had worked at the prison. Finally Powers emphasized that, notwithstanding Lynds' enthusiasm in exercising authority, the central principle of Auburn continued to be "that physical force should be applied to create and sustain moral power". ${ }^{33}$

Cruelty and the Public Sphere

As much as the efforts of Powers and others sought to articulate a clear moral rationale for penal violence that could distinguish it colonial punishments and still legitimately claim to be working under the spirit of the penitentiary the seeming aptitude of prison officials for excess greatly undermined this effort. The severity of treatment was impressive for both its ingenuity and ubiquity. For example, an investigative committee in 1832 found that in the marble quarries of Sing Sing prison, 4 to 5 convicts at a time were harnessed to carts and forced to draw heavy marble loads from the quarry to the prison yard.

"The committee do not pretend to claim for themselves an unusual degree of sensibility... believing they are acquainted with, and enjoy in common the feelings of the citizens among whom they respectively reside, they can not withhold the expression of their deep humiliation, as members of the enlightened and humane community, when they witnessed their fellow beings doomed to so ignominious, so degrading a punishment."34

Yet the above committee, while confirming that much of the convict testimony it heard corroborated the substance of the accusations of malnutrition and cruelty at Sing Sing,

\footnotetext{
${ }^{33}$ Gershom Powers, Letter of Gershom Powers in Answer to a Letter of the Hon. Edward Livingston, in Relation to Auburn State Prison (1829)

${ }^{34}$ NYSA, Documents of Assembly of the State of New York (1833), Document No. 191, p.1112.
} 
dismissed the charges because prisoner testimony was, by definition, unreliable. At the same time, it assured the legislature that their investigation of Auburn prison confirmed that "...the history of the world has not within a very few years presented so imposing a moral spectacle." 35 If Sing Sing's convicts complained of starvation and undiscriminating violence, Auburn's prisoners humbly submitted to the institution's rules and regulations, testified to the abundance of clothing and food, and proclaimed the minimal corporal punishments they received deserved and just. While the former group's testimony was by definition suspect, the latter represented a testament to the kindness, mildness and benevolence of Auburn's authorities.

The 1833 committee report illustrates an important strategy for reconciling the competing demands of transparency and opacity. Auburn, the public face of the penal system and the only institution open to public visitation was typically portrayed in a highly favorable light. Sing Sing whose prisoners came from New York City and characterized as hardened criminals, was portrayed as a necessary container of violence and terror. This representational division of labor between the two institutions proved remarkably stable and lasted well into the late 1840s. Even when a political realignment in 1838 ousted Democrats from the Governor's office and the State Assembly and the new Whig majority sent an investigative committee to both institutions, it was Sing Sing that figured prominently in the report.

The Assembly investigation in 1839 was significantly different from most that had preceded it. Although the state's claims to transparency forced the legislature to investigate abuse and cruelty frequently between 1826 and 1845 (e.g., in 1826 alone 7 committees of the legislature were sent to Auburn), the committees tended to be highly sympathetic to the perspective of prison authorities and rarely reproduced any damning testimony. Charges of sadistic beatings and starvation were consistently alluded to but these were generally

${ }^{35}$ Ibid, p. 7. 
rationalized as unavoidable outcomes of prison architecture, of the sort of labor practiced or (in Sing Sing's case) the hardened disposition of convicts. In this sense the 1839 investigation, represented a dramatic about face. The committee did not merely summarize the testimony it heard but reproduced the detailed accounts of forty-three guards and contractors in its appendix. The candor of the staff was probably attributable to the reversal of their political fortunes; prison appointments had long been part and parcel of the political spoils system and the legislature's periodic investigations and committee evaluations had often followed in the wake of political realignment. The ascendancy of the Whig party held the very real possibility that many keepers might lose their posts if they proved uncooperative.

The testimony laid bare the unmitigated sadism of the administration and the plight of malnourished and half-starved convicts. For example, Giles Leach a contractor for the Boston Leather Company testified that he had witnessed a convict named Howell stripped naked, bound with ropes to a vice and whipped for three successive days with the cat o' nine tails (a whip with six tightly wound tails made of three-quarters of an inch of wire) with upwards of 200 blows each time. An assistant keeper, Robert Lent testified that he knew of at least five or six convicts that had committed suicide in despair at their treatment and that had been secretly buried without notifying the coroner. ${ }^{36}$ More troubling still, the warden and his guards beat the institution's numerous mentally ill convicts savagely and for sport. This testimony was then widely disseminated and reprinted in full in the subsequent Whig newspaper coverage. ${ }^{37}$

${ }^{36}$ NYSA, Documents of Assembly of the State of New York, Document No. 335 (1839), pp.17-19.

${ }^{37}$ See for example: "From the Peekskill Republican", Hudson River Chronicle, January 4, 1839; "Sing Sing Prison", Hudson River Chronicle, April 2, 1839; "Testimony", Hudson River Chronicle, April 23, 1839 (which publishes the testimony in full); "State Prisons", Hudson River Chronicle, April 30, 1839; "State Prisons", Hudson River Chronicle, June 4, 1839 (which records the reactions in the legislature). 
The 1839 investigation represents the first crack in the state's unified portrayal of penal institutions and its monopoly over prison facts. Later that year, a committee appointed by the Democratically held senate would conduct its own investigation and exonerate the warden and his staff, but Sing Sing's top administrator was forced from office in 1840 and new Whig-leaning wardens were appointed at both Sing Sing and Auburn. The new administrations actively critiqued the use of the lash and explicitly framed discipline against corporal excess. New controls were implemented over flogging and at Auburn the lash was dispensed with entirely in favor of the "shower bath". The shower bath represented a particularly effective resolution of the problematic of violence: it left no welts and marks and had the endorsement of the prison's medical staff, yet it also involved an escalation of disciplinary sanctions. It involved strapping a convict to a chair placed under a suspended tank of cascading water; the water could be iced, the height of the cascade adjusted and a perforated bowl placed around the neck to induce an effect similar to drowning.

If illegitimate and despotic violence left its victims bloody and scarred, inscribing on their bodies a visible account of penal violence, the effects of the shower bath defied visibility; they fit neatly within the Whig narrative of modernization and freedom from tyranny. In their annual report, Auburn's inspectors noted the efficacy of the new punishment and its superiority to the lash because it allowed the punished to retain his "self-respect". Auburn's medical officer further recommended broadening its use to all the state's institutions describing it as the "most efficient, time-saving and humane mode of punishment, that could be devised., 38

The Whig attack on corporal punishment and the state's use of violence largely took place within the press and the public sphere; their print networks were formidable and significant editorial resources were directed upon discrediting the previous administration's

38 “Auburn State Prison. Cold Water Punishment," Hudson River Chronicle, March 28, 1843. 
disciplinary practice. Yet the success of their critique also spoke to the shifting terrain of cultural sensibilities concerning the meaning of suffering. A new sensitivity to pain and a willingness to empathize with the suffering of others linked disparate reform movements that ranged from campaigns against animal vivisection to anti-slavery; these movements expressed a growing sensibility with regards to the body and channeled the undercurrent of public concern with the suffering of prisoners. Cultural elites became increasingly concerned with the moral effect of cruelty on perpetrators and spectators. Animal blood sports like bull baiting and cock fighting were the subject of reformer campaigns and animal cruelty laws were passed in New York, Massachusetts, Connecticut and Wisconsin. These broad initiatives spoke to an aversion to pain and suffering as well as the worrisome fear that such events might transmit a propensity for cruelty towards other human beings. ${ }^{39}$

These diffuse sentiments fed public suspicion concerning cruelty and the use of violence in the state's prisons. For example, at the same time as the 1833 investigation was lauding the moral governance of Auburn, a petition by 54 of the town's leading citizens was before the governor charging the warden with unnecessary cruelty, demanding his resignation and a reform of the inspection system. And despite the fact that a special committee appointed to investigate the charges exonerated the warden the following year, the Assembly was again called upon to answer charges of a "Cat-ocray" at Sing Sing from a former convict that had published an expose in $1833 .{ }^{40}$ Similarly although the 1839 committee focused on Sing Sing, the death of a mentally ill Auburn convict from flogging and the warden's subsequent decision to dispense with a coroner's inquest, spurred an angry crowd of citizens to gather outside the prison gates and demand that local physicians examine the body. The

39 James Turner. Reckoning with the Beast: Animals, Pain, and Humanity in the Victorian Mind (1980), p.30; David Favre and Vivien Tsang, "The Development of Anti-Cruelty Laws During the 1800s," Detroit College of Law Review (1993).

${ }^{40}$ NYSS, "Report of the Committee on State Prisons," (1833), No. 85, p.1; NYSA, "Report of the Committee on State Prisons on the petition of Lewis S. Burr" (1834), No. 211, p.1. Lewis S. Burr, A Voice From Sing Sing (1833), p.16. 
public mood was so inflamed that the warden resigned before a senate committee convened to look into the charges had the chance to exonerate him. ${ }^{41}$

Thus what was distinctive about the representation of violence post-1840 was not that cultural sensibilities had shifted overnight, but that rather that the state's monopoly over its representation was increasingly challenged. On the one hand, it was under assault from within the legislature itself as the Whig party capitalized on the popular mood and committee investigations to characterize the lash as despotic. On the other, newspapers and the press, long uncritical outlets for the reproduction of state speech, came to find that readers were highly receptive to investigative accounts of the state prison system. Newspaper editors and reformers championed the commonality of pain and appealed to the basic and widespread recognition that it in other facets of social life, for example medicine, it could be dominated. Pain was increasingly characterized as despicable and loathsome, a radical departure from traditional views that saw it as unavoidable or punishment for $\sin ^{42}$ This was the first step in a broad rereading of the plight of prisoners through the prism of universal human experience. $^{43}$

Public sensibilities and critique in the public sphere helped set the stage for the portrayal of violence in the 1840 s. Just as the new "humane" mode of punishment was gaining traction, the state elections of 1844 returned democrats to power in New York and in the Federal government. A new democratic board of prison inspectors appointed Elam Lynds

\footnotetext{
${ }^{41}$ W. David Lewis, From Newgate to Dannemora (1965), pp. 207-208.

${ }^{42}$ Karen Halttunen, "Humanitarianism and the Pornography of Pain in Anglo-American Culture" The American Historical Review (1995), p.311.

${ }^{43}$ A case in point was the reorientation of professional medical values after 1845 . The isolation of morphine and a successful surgery using ether as an anesthetic, shifted cultural assumptions about pain virtually overnight. For doctors the alleviation of pain became an integral part of official duty (as opposed to an incurable disease) and the public eagerly supported a burgeoning market of home remedies and painkillers offering the promise of a life without bodily pain. David B. Morris, The Culture of Pain (1991), pp.61-65; Martin S. Pernick, A Calculus of Suffering: Pain, Professionalism, and Anesthesia in $19^{\text {th }}$ Century America (1985) pp. 72-83.
} 
(a long-running advocate of whipping) as the new head of Sing Sing, much to public chagrin. The results were predictable: floggings returned with a vengeance — at one point reaching a monthly total of 1500 lashings. The warden's tenure, however, lasted only eight months and was plagued by negative press and in-fighting with the prison's inspectors. ${ }^{44}$ The incident underscored just how unstable penal violence had become as well as the legislature's tenuous hold over its portrayal. Even the Boston Prison Discipline Society (BPDS) ran a long editorial note in its 1841 report withdrawing its support for flogging and openly questioning whether corporal punishment was indispensible to penal discipline.

In response, the democratic legislature sought to mitigate the negative publicity through increasing the transparency of its penal system. In 1844, it threw its support behind the creation of the New York Prison Association (NYPA) and granted the new reform society unprecedented powers. It was to inspect all county, city and state penal establishments and was given legal authority to interview convicts in private about the treatment they were receiving. The state had effectively created a second inspection committee that would submit annual reports and supplement the work of the state prison inspectors; its support of the NYPA spoke to the newly transformed reality of penal publicity. The Lynds incident invigorated the Whig opposition and critique of the prison system continued in the press. At the same time the state's most vocal and influential advocate (the BPDS) was undergoing a leadership struggle over its commitment to the Auburn system. In 1845, it would publish a “minority report" which gave a favorable endorsement of Pennsylvania's prison system for the first time in its history. ${ }^{45}$ Thus it is likely that when the legislature amended the NYPA's

\footnotetext{
${ }^{44}$ John W. Edmonds, A Letter From John W. Edmonds, One of the Inspectors of the State Prison at Sing Sing to General Aaron Ward, In Regard to the Removal of Capt. Lynds, As Principal Keeper of That Prison, New York, February 2, 1844, p.4.

${ }^{45}$ BPDS, Report of the Minority Special Committee of the Boston Prison Discipline Society (1845).
} 
charter to include investigative powers it envisioned it had secured a local advocate to fill the vacuum left by the BPDS.

Yet rather than attenuating the crisis of penal representation, the entry of the NYPA further destabilized the legislature's monopoly over prison facts. Just two years into the exercise of its new inspection powers, the association was under attack in the legislature, barred from state prisons and openly feuding with the board of inspectors. ${ }^{46}$ Its third report detailed how beef paid for by the state was replaced with mutton and how guards routinely fed prisoners spoiled fish for profit. It compared one agent's annual report against the prison's invoices and uncovered a deficit of $\$ 21,000.00$ rather than the small budgetary surplus that had been reported. The most controversial portion of the report, however, dealt with corporal discipline. It recounted the punishment of a black Sing Sing prisoner (named Orange) for fighting with another convict in the yard.

“...Guards were sent for, and Mr. C. struck me with a club. I struck Mr. Coates. The Guards pricked me with their bayonets and I ran into the cell. I have three scars where I was stabbed. I was in the cell; they asked me to come out. I told them they might as well kill me in the cell as out. They sent for hooppoles [sic] and punched me till I could not stand. They then caught me by the heels and dragged me out, tied me up, whipped me, and then put me here. Three of them whipped me - gave me about fifteen lashes apiece. I was kicked in the head when dragged out of my cell by Mr. Van Wart. While I was in the cell Mr. Eldridge fired at me with a pistol, which took effect in my wrist. After the whipping they put me in here, and kept

\footnotetext{
${ }^{46}$ W. David Lewis, From Newgate to Dannemora (1965), pp. 219-223; M. J. Heale, "From City Fathers to Social Critics: Humanitarianism and Government in New York, 1790-1860." The Journal of American History (1976).
} 
me on bread and water eight months. My legs were shackled. The shackles were only removed yesterday. My wrist is not sound yet." 47

Orange's harrowing ordeal emphasized how little had changed since 1839 and undermined the logical coherence of the law of "necessity". Given that the prisoner was already contained in his cell there was little reason to drag him out by force for immediate punishment and even less reason to shoot him and taunt him with bayonets. Moreover, Orange's account was subversive because it was reproduced alongside the testimony of the five officials involved in the incident; effectively placing the prisoner's word on the same footing as that of his guards. In doing so, the NYPA challenged the powerful legal taboo of civil death and the epistemic violence that sat at the core of official representations of prison life. The coherence of official reports and prison facts relied on the systematic elision of convict self-narratives, their incapacity to testify in court or serve as witnesses, and the enforced regime of silence and self-curtailment of the disciplinary system. ${ }^{48}$

The NYPA, on the other hand, insisted that interviewing every state convict was the only reliable way to arrive at a factually accurate portrayal of state institutions. It was this contentious stance, as well as the association's systematic critique of the factual reliability of official reports, that led to its feud with state prison inspectors. For many years, the NYPA was effectively barred from access to state prisons. In lieu of direct access, the association garnered most of its information through written correspondence with prison officials, minute consideration and critique of the inspectors' own reports to the legislature, and copious interviews with newly released convicts. Initially, it confined its commentary of released

\footnotetext{
${ }^{47}$ NYPA, Third Report of the Prison Association of New York, Committee on Prison Discipline, (1846), p.75

${ }^{48}$ On legal practice of civil death see: Caleb Smith, The Prison and the American Imagination (2009); Joan Dayan, The Law is a White Dog (2012); Luca Follis, "Resisting the Camp: Civil Death and the Practice of Sovereignty in New York State," Law, Culture and the Humanities (2011).
} 
convicts to questions of rehabilitation and recidivism but by 1850 , it began reproducing their testimony concerning internal conditions and punishments (the report of 1850 alone provided thirty-four ex-prisoner accounts of violence and neglect). In subsequent years, the NYPA would focus much of its efforts on released convicts, folding its concern with the prison conditions within individual narratives of the post-incarceration life of convicts. These biographical "case-studies" maintained the same general structure over the years and focused upon: where the convict had served their time, the living conditions in prisons, the kind of punishments they had endured, as well as the motives behind their crimes and their own assessment of reformation. These "case studies" helped break the strict monopoly of the state over the portrayal of penal conditions and the "facticity" of official reports. At the same time, these accounts, composed as they were, in the convict's own words humanized the plight of those that had, up until then, merely been aggregate numbers in state reports. ${ }^{49}$

Ultimately, it was the death of yet another mentally ill convict, Charles S. Plumb, at Auburn in February of 1846 that convinced the legislature to abandon the lash. The coroner's inquest determined that Plumb had been whipped in three separate incidents. Once for shattering a window and throwing out a jug of oil in the workshops; a second time for replying "steamboat" when he was interrogated as to his name after he had been making whistling sounds in his cell; and a third time for ripping some clothes, books and bedding in his cell. According to the Warden and prison officers Plumb's whipping was a necessary punishment to maintain discipline and did not exceed twelve lashes. The postmortem examination found the prisoner's back so badly lacerated that it was impossible to tell how

\footnotetext{
${ }^{49}$ A typical example of these case studies from the report of 1860: "No. 27.-Was sentenced to Sing Sing for two years for stealing two chests of tea. He says to agent, 'I was guilty; frequenting dance houses, gambling saloons, and low theatres did it; I know what ruined me then; I hope to avoid such places in the future. I was punished several times whilst there; my keeper was a severe man; I was once showered for not sweeping to please him, and twice for not performing my task. I hope to be kept from dishonesty all my life.' Assistance was rendered to him until laboring work was provided for him." NYPA, Thirteenth and Fourteenth Report of the Prison Association of New York (1860), p. 61.
} 
many lashes had been inflicted but estimated the number to be between 360 and 600 . The press accounts openly questioned the superior humanism of the Auburn system:

"Had this crime been committed...in any of the states where the "brutal" system of the "public whipping post" is retained, he would probably have been punished by a designated officer, to the extent of some 30 or 40 blows...in the presence of all who chose to see the infliction — and here the law would have been satisfied... This would have been the course under what has been generally designated as the "brutal code of the whipping post"...Is there a person who can doubt for a moment as in the comparative humanity of the two systems?",50

Later that year, the senate tasked the committee on state prisons to consider "numerous petitions praying that a law be passed abolishing the use of the whip in our penitentiaries". The report, after summarizing some fifty years of investigations into cruelty and abuse and providing a reconstruction of the legislature's attempts to legally regulate violence, underscored the longstanding public aversion to penal violence and argued for the abolition of corporal punishment. ${ }^{51}$ The legislature responded in 1847 by abolishing the use of the whip and explicitly prohibiting striking, flogging or beating inmates as a disciplinary device. Henceforth, the use of force was only authorized in self-defense or to prevent riots and the only form of punishment explicitly endorsed by law was solitary confinement.

A series of punishments involving stress positions and "clean" forms of corporal duress (e.g., the shower bath, the pulley, the yoke and bucking) would continue to dominate penal space and produce scandal well into the 1880 s. The state discourse that surrounded

\footnotetext{
50 "The Coroner at the Prison," Auburn Journal, February $4^{\text {th }} 1846$. See also: Flogging in Prisons" Prisoner's Friend, May 20, 1846, pg. 80; "General Intelligence," New York Evangelist, Feb 5, 1846, pg. 23.

${ }^{51}$ NYSS document no. 118 (1846) 20
} 
these punishments admitted their inadequacy even as it emphasized the restraint and pity it inspired in prison officials:

"Many of the subordinate keepers were free in their opinions that the shower bath is a much more cruel punishment than the cat. But there is one important difference where they seemed not so well convinced... while the use of the lash hardens the keeper and stimulates his angry passions, the contemplation of his victim under the water excites his pity and better feelings. The shower-bath cools his passion while the whip inflames it." 52

\section{Conclusion}

The collection and dissemination of prison facts was a knotty issue that emphasized the gap between two aspects of the state in $19^{\text {th }}$ century New York. On the one hand, the state's administrative decentralization and high turnovers in office gave it a tenuous grasp over the management of its institutional projects. In this context, state prisons were allowed to govern themselves with little oversight and directed central policy—at times becoming veritable fiefdoms. On the other hand, the state represented itself in print, in law, and before its constituents as a unitary, centralized and comprehensive entity capable of concentrating its force into the very minutia of institutional life. If the collection of prison data and the publishing of annual reports was, at least in part, a strategy designed to reconcile these two discordant realities along the lines famously intimated by Philip Abrams, it was also a

\footnotetext{
${ }^{52}$ NYSA, "Report of the Committee Appointed to Examine the Several Prisons," Document No. 20 (1852), p.27.
} 
genuine attempt to uncover how prisons were actually run and to hold them to some kind of legislatorial oversight. ${ }^{53}$

At the same time, valorizing transparency and accountability in the production of information complicated the possibility of using that same information for the uses of control. A number of scholars have understood state processes of information gathering as synonymous with social control but this paper has sought to illustrate the point that, at least in $19^{\text {th }}$ century America, the liberal democratic state's emphasis on visibility and accessibility directly subverted attempts to deploy that information for strategies of domination. ${ }^{54}$ The ubiquity of prison violence, the scandals and negative press it engendered, as well as the sustained public suspicion of state disciplinary practices were significant crises of governance. In responding to these crises the state was forced to articulate a clear rationale for the legitimate use of violence and the discretionary powers of public authorities; it deployed investigative committees and spent considerable time honing its public image. Ultimately, it was forced to abandon the use of corporal violence and, in the late $19^{\text {th }}$ century, would dramatically reshape the administration of its prison system to insulate it from politics. Yet by the eve of the Civil War, the value of prisons, their viability as public institutions (which would be supported at public expense if need be) and their compatibility with democratic statehood—all highly contentious notions throughout the antebellum period—had been ideologically sustained and legitimated.

\footnotetext{
${ }^{53}$ Philip Abrams, "Notes on the Difficulty of Studying the State," Journal of Historical Sociology (1988).

${ }^{54}$ E.g., Michel Foucault, Discipline and Punish (1977), p.469. James C. Scott, Seeing Like a State (1998), Ch. 2; Edward Higgs, The Information State in England (2004), Ch. 2; Christopher Dandeker, Surveillance, Power \& Modernity (1990); Christian Parenti, The Soft Cage: Surveillance in America from Slavery to the War on Terror (2003).
} 